\title{
Metode RF Filter untuk Perbaikan Kinerja Received Total Wideband Power pada Sistem UMTS
}

\author{
M. Adi Surya Antara ${ }^{1}$, N. Gunantara ${ }^{2}$, NMAED Wirastuti ${ }^{3}$
}

\begin{abstract}
Cellular communication system with multiple network operators operate on a co-located area (heterogeneus network) causing effect of radio frequency interference. RTWP (received total wideband power) value emerges as indicator radio frequency interference on UMTS system, which is primary contribution of degraded $\mathrm{QoS}$ cellular communication system. $R F$ filter butterworth circuit two half section resulted as optimal design to reach the goal compare to the other circuit section. By implemented RF filter has showed improvement indicator perform RTWP on UMTS network operator.
\end{abstract}

Intisari- Pada komunikasi seluler dengan multiple operator yang beroperasi pada area geografis yang berdekatan (heterogeneus network), diantaranya menyebabkan efek interferensi yang tinggi, Salah satu indikatornya adalah ditemukan permasalahan RTWP (Received Total Wideband Power) pada sistem UMTS (Universal Mobile Telecommunication System), yang mana menjadi salah satu kontributor utama penurunan QoS pada jaringan komunikasi seluler. Tipe $R F$ filter butterworth circuit two half section didapatkan sebagai desain $R F$ filter yang paling optimal dibandingkan circuit section lainnya. Dengan diimplementasikannya $R F$ filter menghasilkan perbaikan performa indikator $R T W P$ pada jaringan UMTS operator.

Kata Kunci- RTWP, radio interferensi, $R F$ band pass filter, UMTS, Circuit section

\section{PENDAHULUAN}

Permasalahan pada jaringan selular sangatlah kompleks seperti noise, fading, dan interferensi. Permasalahan tersebut merupakan gangguan yang dapat menurunkan QoS (quality of service) dalam jaringan selular [1]. Dengan banyaknya operator yang beroperasi diantaranya menyebabkan efek interferensi yang tinggi dalam pengoperasiannya, salah satu indikatornya adalah ditemukan permasalahan RTWP (Received Total Wideband Power) pada sistem UMTS (Universal Mobile Telecommunication System), yang menjadi salah satu kontributor utama penurunan QoS pada jaringan komunikasi nirkabel dan bergerak [2].

\footnotetext{
${ }^{1}$ Mahasiswa Teknik Elektro, Magister Bisnis Telekomunikasi Universitas Udayana, Jln. Jalan Kampus Bukit Jimbaran 80361 INDONESIA; e-mail: adisurya_antara@yahoo.com)

${ }^{2,3}$ Dosen, Jurusan Teknik Elektro dan Komputer Fakultas Teknik Universitas Udayana, Jln. Jalan Kampus Bukit Jimbaran 80361 INDONESIA (telp: 0361-703315; fax: 0361-4321; e-mail: nyomangunantara@gmail.com \& arydev_02@yahoo.com)
}

M.Adi Surya Antara:Metode RF Filter untuk ...
Interferensi radio frekuensi adalah faktor kunci yang mempengaruhi kualitas dari jaringan selular. Secara umum interferensi radio frekuensi terdiri dari eksternal dan internal interferensi. Eksternal interferensi diperoleh dari repeater, radar, analog base transceiver (BTS) TV station, dan walkietalkie. Internal interferensi diperoleh dari self-interference atau interferensi dari dalam sistem itu sendiri, yang dapat disebabkan oleh ilegal terminal, permasalahan parameter setting, BTS fault equipment, in-band and out-of-band interference. Hasil dari interferensi yang ada membawa beberapa dampak pada sistem seperti : sensitifitas BTS berkurang, penurunan kapasitas sistem, bertambahnya call drop rate, menurunnya access success rate, call quality, call drop, handoff, conversation quality, network coverage, dan capacity [3].

Beberapa penelitian berkaitan dengan interferensi radio frekuensi telah dilakukan, penelitian pertama membahas tentang total interferensi dalam jaringan dengan menggunakan simulasi monte carlo dengan hasil performa jaringan dievaluasi [4]. Penelitian kedua membahas tentang efek interferensi dan noise rise dari emisi spurious dampak dari performa coverage dan kapasitas sistem yang dikembang dengan hasil penggunaan strategi co-location channel spektrum bandwith antar operator [5]. Penelitian ketiga membahas tentang solusi penekanan interferensi co-channel dan adjacent channel pada sistem WCDMA, dengan hasil ada perbaikan pada nilai DTF, RL, dan VSWR pada BTS yang dipasangkan $R F$ filter [1].

Dari penelitian sebelumnya tersebut, maka dalam paper ini membahas permasalahan interferensi radio frekuensi dengan adanya indikator RTWP pada operator UMTS di wilayah Denpasar. Kondisi wilayah kota Denpasar yang terdiri dari multiple operator selular serta jarak diantara BTS ke BTS antar operator yang berdekatan yang beroperasi di area tersebut, merupakan salah satu kontributor tingginya event interferensi radio frekuensi. Dengan kondisi yang ada menyebabkan banyak ditemukan permasalahan RTWP pada sistem UMTS operator, jika dibandingkan dengan area lainnya di wilayah Bali permasalahan interferensi yang ada cenderung lebih sedikit jumlahnya. Pada penelitian ini dijelaskan identifikasi node yang terdapat permasalahan RTWP, metode $R F$ filter dengan beberapa kombinasi orde circuit filter [6], dan perbaikan yang dicapai setelah implementasi $R F$ filter pada sistem UMTS. Skema penelitian ini belum ada yang memaparkan pada penelitian sebelumnya, sehingga operator selular mendapatkan solusi atas permasalahan interferensi yang ada.

Permasalahan RTWP ini sangat merugikan, sehingga operator selular dituntut perlu melakukan penanganan untuk menemukan solusinya. Beberapa aspek yang masih diteliti saat ini sebagai penyebab dari munculnya permasalahan RTWP adalah instalasi node, adjacent channel interferensi, 
overload traffic sektoral pada node UMTS, serta utilisasi kanal blok frekuensi UMTS 2,1 GHz yang masih dilanggar penggunaannya oleh user radio frekuensi. Blok frekuensi 2,1 $\mathrm{GHz}$ telah ditentukankan oleh MenKomInfo selaku badan regulasi yang mengatur penggunaan kanal blok frekuensi pada masing masing operator seluler [7]..

\section{RF FILTER DAN UMTS}

\section{A. Sistem UMTS}

Arsitektur jaringan UMTS terdiri dari perangkatperangkat yang saling mendukung, yaitu User Equipment (UE), UMTS Terresterial Radio Access Network (UTRAN) dan Core Network (CN) dapat dilihat pada Gambar 1 [8].

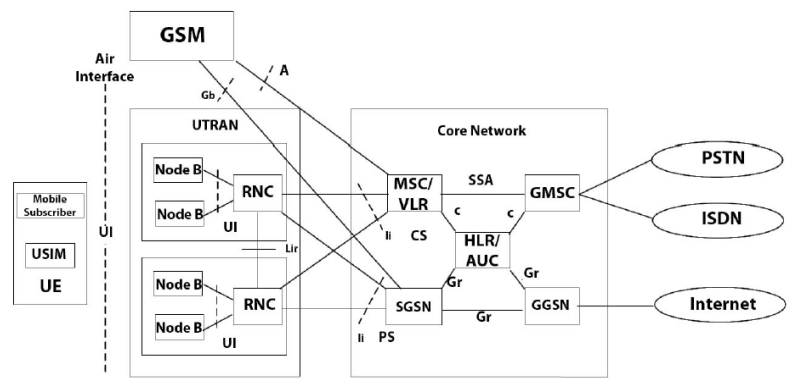

Gambar 1. Arsitektur Jaringan UMTS

Jaringan akses radio menyediakan koneksi antara terminal mobile dan Core Network. Dalam UMTS jaringan akses dinamakan UTRAN (UMTS Terrestrial Radio Access Network). UTRAN terdiri dari satu atau lebih Jaringan SubSistem Radio (RNS). Sebuah RNS merupakan suatu subjaringan dalam UTRAN dan terdiri dari Radio Network Controller (RNC) dan satu atau lebih Node B. RNC dihubungkan antar RNC melalui suatu Iur Interface dan Node B dihubungkan dengan satu Iub Interface [8],[9].

\section{a. RNC (Radio Network Controller)}

RNC bertanggung jawab mengontrol radio resources pada UTRAN yang membawahi beberapa Node-B, menghubungkan CN (Core Network) dengan user, dan merupakan tempat berakhirnya protokol RRC (Radio Resource Control) yang mendefinisikan pesan dan prosedur antara mobile user dengan UTRAN.

\section{b. Node-B}

Node-B sama dengan Base Station di dalam jaringan GSM. Node-B merupakan perangkat pemancar dan penerima yang memberikan pelayanan radio kepada UE. Fungsi utama Node$\mathrm{B}$ adalah melakukan proses pada layer 1 antara lain: channel coding, interleaving, spreading, de-spreading, modulasi, demodulasi dan lain-lain. Node-B juga melakukan beberapa operasi RRM (Radio Resouce Management), seperti handover dan power control.

\section{c. CN (Core Network)}

Jaringan Lokal (Core Network) menggabungkan fungsi kecerdasan dan transport. Core Network ini mendukung pensinyalan dan transport informasi dari trafik, termasuk peringanan beban trafik. Fungsi-fungsi kecerdasan yang terdapat langsung seperti logika dan dengan adanya keuntungan fasilitas kendali dari layanan melalui antarmuka yang terdefinisi jelas, yang juga pengaturan mobilitas. UMTS juga dihubungkan dengan jaringan telekomunikasi lain, jadi sangat memungkinkan tidak hanya antara pengguna UMTS mobile, tetapi juga dengan jaringan yang lain.

- MSC (Mobile Switching Center)

- VLR (Visitor Location Register)

- HLR (Home Location Register)

- SGSN ( Serving GPRS Support Node)

- GGSN ( Gateway GPRS Support Node)

Sistem UMTS 2.1 GHz yang diatur oleh MenKomInfo di Indonesia ditunjukan pada Gambar 2. Dijelaskan pada gambar penataan frekuensi $2.1 \mathrm{GHz}$ pada frekuensi up link dimulai dari range $1920 \mathrm{MHz}-1980 \mathrm{MHz}$ serta frekuensi down link pada range $2110 \mathrm{MHz}-2170 \mathrm{MHz}$. Pada penelitian ini membahas frekuensi uplink UMTS. Tiap operator seluler mendapatkan alokasi frekuensi sebesar $5 \mathrm{MHz}$ per blok, penyediaan dan pengaturan blok frekuensi $2,1 \mathrm{GHz}$ ini menyesuaikan dengan proses seleksi yang dilakukan oleh MenKomInfo RI dan dilegalkan dengan keluarnya keputusan menteri untuk penggunaan setiap blok alokasi frekuensi 2,1 $\mathrm{GHz}$ sehingga kedepannya tidak ada operator yang melakukan pelanggaran penggunaan alokasi frekuensi [7].

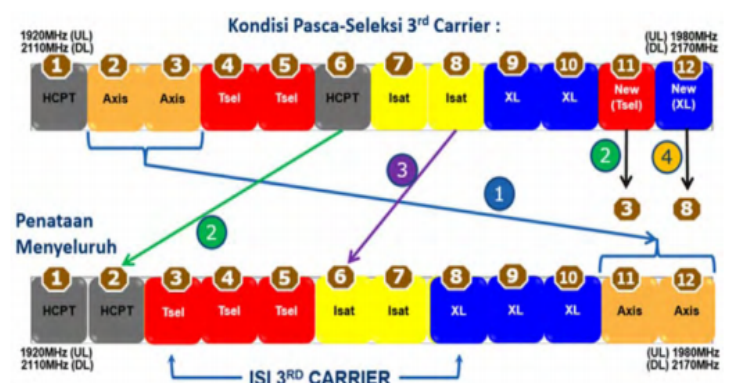

Gambar 2. Penataan frekuensi 2,1 Ghz pada operator seluler oleh Menteri Komunikasi dan Informatika

\section{B. RTWP}

RTWP diartikan sebagai received total wideband power adalah total daya dari keseluruhan sinyal terima dalam band frekuensi uplink di cell antenna, sinyal terima berupa channel fisik uplink yang dikirim oleh user equipment atau interferensi dari sumber diluar sistem UTRAN. RTWP dapat juga dikatakan sebagai total noise yang diterima di cell antenna pada frekuensi uplink. Secara umum RTWP mempresentasikan uplink load dalam sistem UTRAN cell seperti ditunjukan pada Gambar 3. Nilai performa indikator RTWP yang diluar dari standar yang sudah ditetapkan mempunyai dampak yang besar dalam layanan kualitas ke user [8],[10].

\section{RF FILTER}

Dalam teori rangkaian, $R F$ filter adalah jaringan elektronik yang merubah amplitudo atau karakteristik phase dari sinyal dengan mengacu pada frekuensi. 


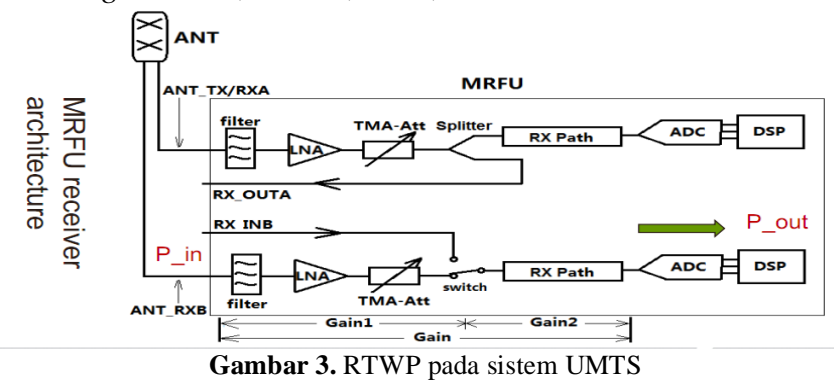

Idealnya, $R F$ filter tidak akan menambah frekuensi baru pada input sinyal maupun merubah komponen frekuensi dari sinyal dan akan merubah amplitudo relatif dari komponen frekuensi yang bermacam macam atau ada hubungan phase dengan frekuensi tersebut dapat dilihat pada Gambar 4. RF Filter digunakan dalam sistem elektronik untuk menekan sinyal dalam range frekuensi yang pasti dan menolak sinyal diluar dari frekuensi range. Dengan begitu $R F$ filter mempunyai gain yang mana tergantung dari sinyal frekuensi [11].

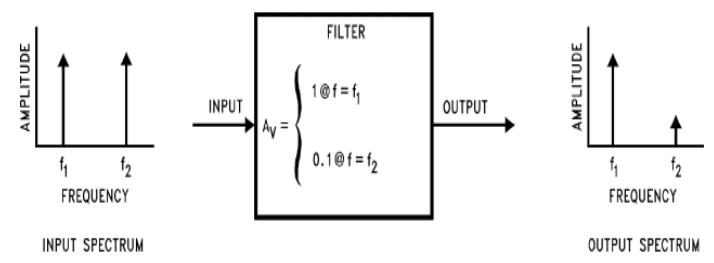

Gambar 4. Peranan filter dalam menekan frekuensi meyesuaikan dengan hasil yang diharapkan.

Tipe dasar dari RF filter ada tiga macam yaitu bandpass, low pass, dan high pass. Penelitian ini akan memakai $R F$ filter tipe band pass menyesuaikan dengan frekuensi center yang bisa dilewatkan dalam rangkaian $R F$ filter ini [6],[11].

\section{a. Respon Filter Bandpass}

Ada perbedaan respon band pass filter untuk bermacam macam keperluan. Sebagai contoh butterworth terkenal baik digunakan ketika tidak ada ripple amplitude pada signal yang diinginkan dalam band pass filter, tingkat selektivitas yang medium, variasi group delay yang medium, dan toleransi pada variasi komponen yang baik (filter lainnya yang mana sensitive terhadap toleransi komponen akan memperlihatkan ketidaksesuaian dan mengubah passband dalam S21 dasn S11, dikarenakan variasi normal dalam nilai $\mathrm{L}$ dan $\mathrm{C}$ ). Filter Chebyshev akan mempunyai jumlah pasti dari ripple passsband yang mana akan dipaksa pada signal input seperti yang dilewatkan pada output filter. Respon chebyshev akan tetapi menawarkan selektivitas yang tinggi, dengan variasi grup delay yang tinggi side effect dari bawaan superior filtering performance (ripple amplitude dan variasi grup delay yang tinggi bisa menyebabkan bertambahnya $B E R$ dalam signal digital, hal tersebut tidak diinginkan). Ripple chebyshev yang rendah bisa secara mudah didesain, dan variasi group delay bisa diperbaiki dengan melebarkan passband filter, atau dengan menggunakan pole yang lebih sedikit. Respon filter Bessel tidak mempunyai ripple dalam bulatan passband mereka dan menampilkan group delay M.Adi Surya Antara:Metode RF Filter untuk ... sangat rendah, tetapi akan mempunyai selektivitas yang begitu rendah dan toleransi yang rendah mutunya terhadap variasi komponen. Ada banyak perbedaan tipe dari circuit filter teknologi LC yang melengkapi respon dari Butterworth, Chebyshev, dan Bessel. Pilihan tergantung dari bentuk passband yang dinginkan, persen bandwidth, sensivitas terhadap toleransi komponen (bersifat parasit reaktansi distribusi), dan kemampuan untuk menghasilkan nilai komponen yang dapat dicapai selama desain [6],[11].

\section{b. Desain Band Pass Filter}

Desain band pass filter dalam penelitian ini, menggunakan metode parameter image. Metode parameter image merupakan suatu framework untuk menganalisa perhitungan nilai dari komponen seri dan pararel dalam filter passive [8]. Desain band pass filter dengan metode parameter image hampir sama dengan prosedur desain $R F$ filter lowpass dan highpass, namun kompleksitas lebih besar dikarenakan komponen dan cutoff frekuensinya dua kali. Seperti desain filter dengan low pass dan high pass, peneliti memulai dengan two half section ditunjukan Gambar 5. Sesuai dengan Gambar 5, pada rangkaian band pass filter setiap pasangan LC adalah single pole, jadi setiap half section terdiri atas dua induktor dan dua kapasitor. Rangkaian band pass filter two half section bisa disambung dari dua rangkaian half section secara bersama sama untuk mendapatkan filter dengan pole yang lebih. Nilai elemen Ro merupakan nilai perbandingan antara besaran impedansi input dan output $\left(Z_{\text {in }} / Z_{\text {out }}\right)$ atau matching impendance, dengan nilai maksimalnya sebesar 50 ' $[6]$.

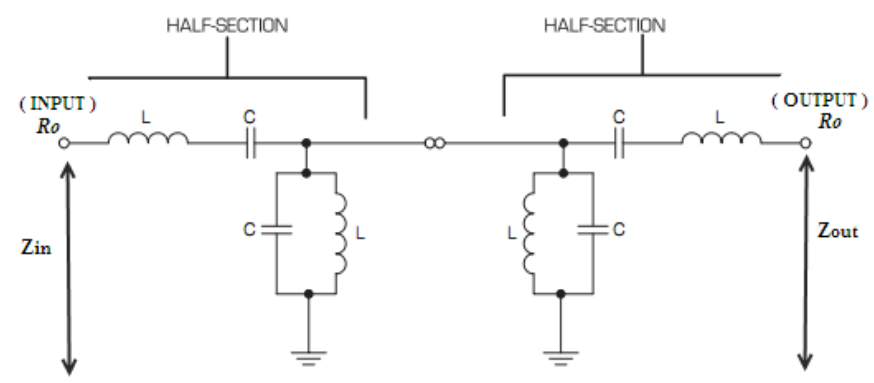

Gambar 5. Susunan rangkaian band pass filter two half section

Untuk mendesain band pass filter dengan metode parameter image, diperlukan perhitungan nilai elemen LC untuk rangkaian half section. Dimana nilai elemen persamaan menjelaskan $L_{s}$ untuk nilai induktansi seri, $C_{s}$ untuk nilai kapasistansi seri, $L_{p}$ untuk nilai induktansi pararel, dan $C_{p}$ untuk nilai kapasistansi pararel. Untuk rangkaian band pass filter two half section seperti pada Gambar 5 diatas, nilai elemen LC dapat dihitung dengan persamaan berikut:

$$
\begin{gathered}
L_{S}=\frac{\left(\frac{R_{0}}{\left(f_{2 c}-f_{1 c}\right) \pi}\right)}{2} \\
C_{S}=2\left(\frac{f_{2 c}-f_{1 c}}{R_{0}\left(f_{2 c} \cdot f_{1 c}\right) 4 \pi}\right)
\end{gathered}
$$




$$
\begin{aligned}
& L_{p}=2\left(\frac{R_{0}\left(f_{2 c}-f_{1 c}\right)}{\left(f_{2 c} \cdot f_{1 c}\right) 4 \pi}\right) \\
& C_{p}=\frac{\left(\frac{1}{R_{0}\left(f_{2 c}-f_{1 c}\right) \pi}\right)}{2}
\end{aligned}
$$

Susunan rangkaian band pass filter two half section yang sudah terdiri dari beberapa pasangan LC atau dua pole ini, dimasukan nilai elemen induktansi dan kapasistansi seri maupun pararel $L_{s}, C_{s}, L_{p}$, dan $C_{p}$. Rangkaian tersebut dapat dilihat pada Gambar 6 [6].

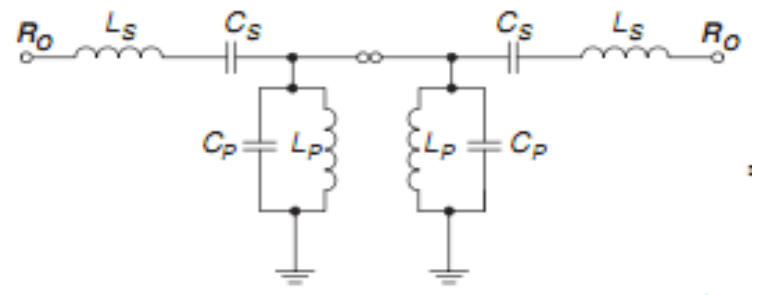

Gambar 6. Elemen $L_{s}, C_{s}, L_{p}$, dan $C_{p}$ pada band pass filter two half section

Dari Gambar 6 dapat disederhanakan menjadi rangkaian seperti Gambar 7. Dari Gambar 7 dapat kita ketahui susunan pasangan LC pararel yang disederhanakan, untuk mendapatkan nilai elemen LC pararel yang fix pada band pass filter two half section [6].

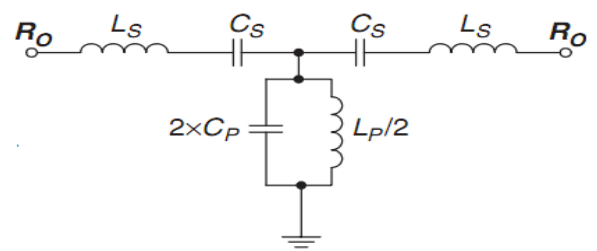

Gambar 7. Penyederhanaan rangkaian two half section band pass filter

\section{c. S parameter}

S-parameter (parameter penyebaran) karakteristik yang berhubungan dengan respon perangkat $R F$ pada point bias dan frekuensi yang berbeda. $S$ parameter sangat berguna dalam menghitung wireless device gain, return loss, stability, reverse isolation, matching network, dan parameter penting lainnya. S parameter digunakan untuk menyesuaikan blok komponen sumber (input) ke beban (output) untuk maksimum gain, maupun menetapkan koefisien refleksi input dan output dari jaringan yang setingkat yang diakhiri pada kedua portnya dengan persamaan $50+j 0$. Koefisien refleksi adalah perbandingan dari gelombang yang dipantulkan terhadap gelombang yang dikirim. Keduanya diukur dalam kualitas dari kesesuaian diantara satu impedansi dengan lainnya atau $V_{\text {reflected }} / V_{\text {forward }}$ dengan kesesuaian.. Koefisien refleksi bisa diungkapkan dalam rectangular $(\Gamma=R \pm j X)$ atau dalam bentuk polar $(\Gamma=P \angle \pm 0)$. S parameter bisa diterapkan pada perangkat setingkat baik active atau passive dan tidak hanya digunakan dalam menghitung kesesuaian elemen circuit tetapi juga mensimulasikan circuit yang lengkap dalam computer untuk gain, stability, dan return loss. $\mathrm{S}$ parameter dideskripsikan dengan $S_{21}, S_{12}, S_{11}$, dan $S_{22} . S_{21}$ adalah koefisien forward transmission merepresentasikan tingkatan gain. $S_{12}$ adalah koefisien reverse transmission merepresentasikan reverse gain (isolasi). $S_{11}$ adalah input koefisien reflection merepresentasikan input dari return loss. $S_{22}$ adalah output koefisien reflection merepresentasikan output return loss. Gambar 8 menunjukan kombinasi dari keseluruhan $\mathrm{S}$ parameter dalam gain dan reflection dalam sebuah kotak untuk memudahkan deskripsi grafis [6],[11].

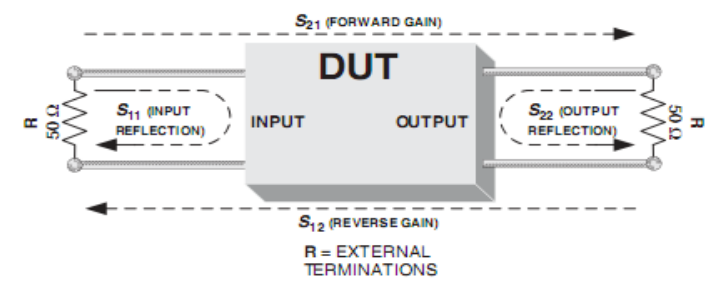

Gambar 8. Two port network menunjukan parameter transmission dan reflection

\section{METODELOGI PENELITIAN}

Pada penelitian ini dirancang pemodelan untuk mengetahui karakteristik $R F$ band pass filter yang akan diimplementasikan pada sistem UMTS. Sebelum proses pemodelan dimulai akan dilakukan pengambilan sampel spektrum frekuensi pada uplink node UMTS yang terdapat gejala interferensi yang tinggi, dari range band frekuensi UMTS operator. Hasil dari pengambilan sampel data spektrum frekuensi node UMTS ini dapat diketahui kondisi eksternal node sistem UMTS operator serta dipakai sebagai acuan dalam simulasi $R F$ band pass filter dengan Matlab2015a.

Urutan tahapan penelitian penanganan RTWP seperti penjelasan diatas lebih detailnya dapat dilihat pada flowchart pada Gambar 9 berikut :

Proses simulasi dengan Matlab2015a melalui desain RF band pass filter detailnya dapat dilihat pada Gambar 10 berikut : 


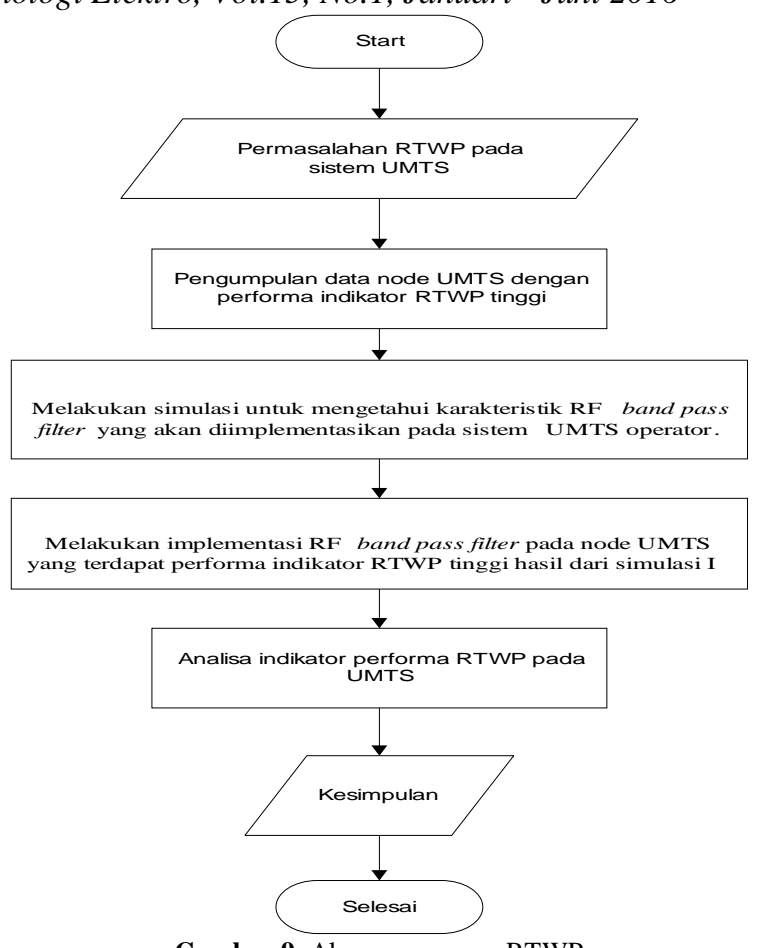

Gambar 9. Alur penanganan RTWP

Tahapan dari Gambar 10 proses desain RF band pass filter langkah langkah detailnya dapat dijelaskan sebagai berikut:

1. Pemilihan nilai induktansi dan kapasistansi menggunakan metode desain image parameter. Pada tahapan ini ditentukan nilai $f_{\text {LOW }}$ dan $f_{H I G H}$ yang dilambangkan dengan persamaan $f_{1 c}$ dan $f_{2 c}$ berdasarkan blok frekuensi $2,1 \mathrm{GHz}$ yang dimiliki oleh operator. Nilai impedansi $R_{O}\left(Z_{\text {in }} / Z_{\text {out }}\right)$ merupakan impedansi input dan output ditetapkan 50 ' $\Omega$.

$\mathrm{Ro}=50 ; \mathrm{flC}=1955 \mathrm{e} 6 ; \mathrm{f2} \mathrm{C}=1980 \mathrm{e} 6 ;$

$\mathrm{Ls}=(\mathrm{Ro} /(\mathrm{pi} *(\mathrm{f} 2 \mathrm{C}-\mathrm{f} 1 \mathrm{C}))) / 2 ;$

$C s=2 *(f 2 C-f 1 C) /\left(4 * p i * R o * f 2 C^{\star} f 1 C\right) ;$

$\mathrm{Lp}=2 * \mathrm{Ro} *(\mathrm{f} 2 \mathrm{C}-\mathrm{f} 1 \mathrm{C}) /\left(4 * \mathrm{pi} \mathrm{f}_{2} \mathrm{C} * \mathrm{f} 1 \mathrm{C}\right) ;$

$\mathrm{Cp}=(1 /(\mathrm{pi} * \mathrm{Ro} *(\mathrm{f} 2 \mathrm{C}-\mathrm{f} 1 \mathrm{C}))) / 2 ;$

2. Menggunakan fungsi rf circuit capacitor dan inductor untuk merencanakan butterworth circuit. Untuk desain 2 port network dengan desain rangkaian blok RLC pararel ditunjukan dengan syntax fungsi rfekt.shuntrlc dan RLC seri rfckt.seriesrlc. Blok RLC yang tersusun secara seri dan pararel tersebut kemudian dikoneksikan bersama menjadi satu circuit bangun dengan syntax fungsi rfckt. cascade

Seg1 = rfckt. seriesrlc('L', Ls, 'C',Cs);

Seg2 = rfckt. shuntrlc('L', Lp, 'C', CP);

Seg3 = rfCkt. shuntrlC ('L', Lp, 'C',Cp);

Seg4 = rfckt.seriesrlc('L',Ls, 'C',Cs);

cktBPF $=$

rfckt.cascade ('Ckts', \{Seg1, Seg2, Seg3, S eg 4 ) ;

M.Adi Surya Antara:Metode RF Filter untuk ...
Gambar 10. Alur prosedur desain RF band pass filter

3. Extract S-parameter dari 2 port network daripada wide frequency range. Ditentukan set frekuensi yang menjangkau passband dari RF filter dan dianalisa dengan referensi 50 ' $\Omega$ pada $Z_{\text {in }}$ dan $Z_{\text {out }}$.

4. Menghitung voltage transfer function dari input ke output. Dilanjutkan dengan fungsi s2tf menghitung fungsi transfer voltage yang dilewatkan pada model S parameter dari circuit.

5. Membuat noisy input voltage waveform. Konstruksi input signal (noisy input voltage waveform) untuk mentesting BPF. Band pass filter memperoleh sinyal sinusoida pada frekuensi centernya, yang mana sebagai noise dengan pencantuman dari zero-mean random noise dan blocker pada frekuensi sebelum $f_{1 c}$ (frekuensi cut off 1 )

6. Hasil input signal dan filter respon dalam domain waktu. Plot sinyal input, sinyal input noise, dan output band pass filter dalam window

p-ISSN:1693 - 2951; e-ISSN: 2503-2372 
7. Hasil input signal dan filter respon dalam domain frekuensi. Lapisan input noise dan respon filter dalam domain frekuensi menjelaskan operasi filtering berjalan dengan baik. Kedua sinyal blocker sebelum frekuensi $f_{1 c}$ dan sinyal noise secara signifikan diredam.

\section{IV.HASIL DAN PEMBAHASAN}

Tahapan awal yang dilakukan peneliti sesuai dengan alur penanganan RTWP pada Gambar 9 adalah melakukan pengambilan sampel data pada node UMTS yang terdapat nilai RTWP abnormal atau diluar dari standart yang ada. Nilai rata-rata RTWP bernilai normal adalah saat nilainya berada pada range $-104,5 \mathrm{dBm}$ sampai $-105,5 \mathrm{dBm}$. Node yang mempunyai nilai RTWP diluar dari standart yang ada pada jaringan UMTS operator XL di wilayah Denpasar salah satunya adalah node 3614387G Pattimura Barat. Nilai RTWP untuk node $3614387 \mathrm{G}$ Pattimura Barat dengan LMT dapat dilihat pada Gambar 11:

Dari Gambar 11 dapat dilihat hasil scanning RTWP dengan LMT bahwa nilai RTWP pada node 3614387G_Patimura barat berada pada range $-89,6 \mathrm{dBm}$ sampai $-86,4 \mathrm{dBm}$. Hasil ini menunjukan bahwa nilai RTWP pada node ini diluar dari nilai normal RTWP.

Untuk mengetahui karakteristik band pass filter yang tepat, maka terlebih dahulu dilakukan pengukuran dengan perangkat spektrum analyzer pada node yang terdapat permasalahan RTWP. Pengambilan sampel pada satu node dipakai sebagai acuan dalam simulasi yang akan dilakukan, adapun node yang discanning dengan spektrum analyzer yaitu pada node $3614387 \mathrm{G} \_P a t i m u r a$ barat.

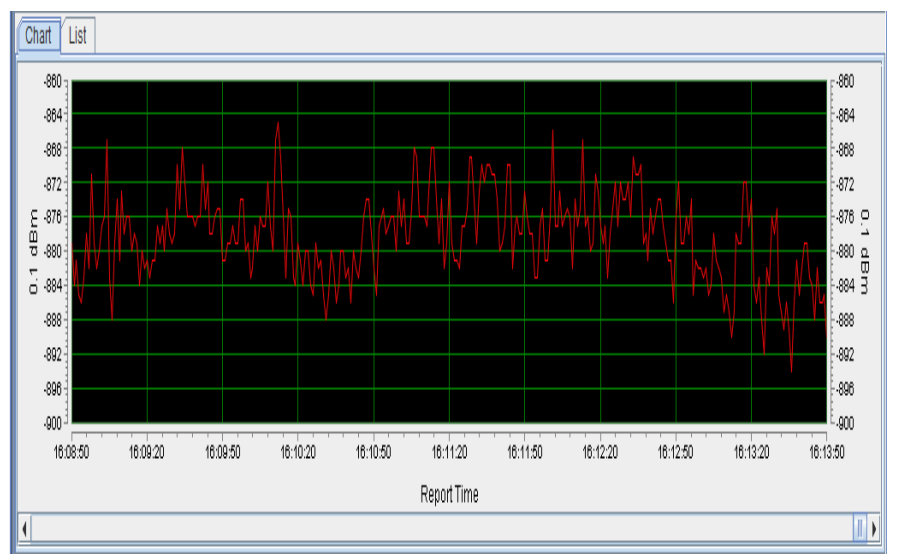

Gambar 11. Scanning RTWP node 3614387G_Patimura barat.

Range bandwidth UMTS yang dipakai sebagai pengukuran pada spektrum analyzer berada pada range frekuensi 1920-1980 MHz, menyesuaikan dengan pita frekuensi radio 2,1 GHz yang ditata dan diatur oleh Menteri Komunikasi dan Informatika RI. Dari pembacaan scanning spektrum analyzer range bandwidth pada Gambar 12 tampak frekuensi uplink UMTS yang terkena noise radio frekuensi adalah range 1982.1 MHz sampai dengan 1990.2 MHz, hal ini diketahui dari adanya magnitude amplitudo yang tinggi pada range tersebut. Nilai magnitude yang normal dari pengukuran didapatkan pada nilai $-120 \mathrm{dBm}$, serta mengalami kenaikan magnitude amplitude sebesar $60 \mathrm{dBm}$ pada range noise radio frekuensi 1982.1 MHz sampai dengan 1990.2 MHz. Noise radio frekuensi itu perlu difilter sehingga menghilangkan efek interferensi pada operator seluler UMTS yang dikenai dampak oleh frekuensi interferensi tersebut. Berdasarkan alokasi frekuensi 2,1 GHz dari Menkominfo untuk Operator XL sendiri memakai alokasi blok frekuensi uplink pada 1955 MHz sampai dengan $1980 \mathrm{MHz}$ dan blok frekuensi downlink pada $2145 \mathrm{MHz}$ sampai dengan $2170 \mathrm{MHz}$.

Untuk menghilangkan interferensi pada range 1982.1 $\mathrm{MHz}$ sampai dengan 1990.2 MHz, diluar dari alokasi blok frekuensi operator XL maka direncanakan simulasi untuk mengetahui karakteristik $R F$ Filter yang tepat untuk mengatasi permasalahan interferensi ini.

\section{A. Simulasi Untuk Mengetahui Karakteristik Band Pass Filter Dengan Circuit Two Half Section}

Dalam simulasi yang akan dilakukan menyesuaikan dengan persamaan 1,2,3 dan 4 pada Bab II Sub Bab 2.3b. Terlebih dahulu ditentukan inputan parameter yaitu : tipe circuit section, range frekuensi operator, dan nilai $R_{o}$ circuit section. Dalam simulasi penelitian ini nilai $R_{o}$ yang digunakan adalah $50 \mathrm{ohm}$. Untuk range frekuensi sistem UMTS pada operator XL berada pada bandwidth 1955 dan 1980 maka nilai inputan parameter $f_{1 c}$ dan $f_{2 c}$ masing masing adalah $f_{1 c}=1955$ serta $f_{2 c}=1980$

Hasil dari perhitungan nilai parameter-parameter dalam rangkaian pada Gambar 4, menghasilkan nilai elemen $L_{s}$, $C_{s}, L_{p}$, dan $C_{p}$ pada circuit two half section sebagai berikut;

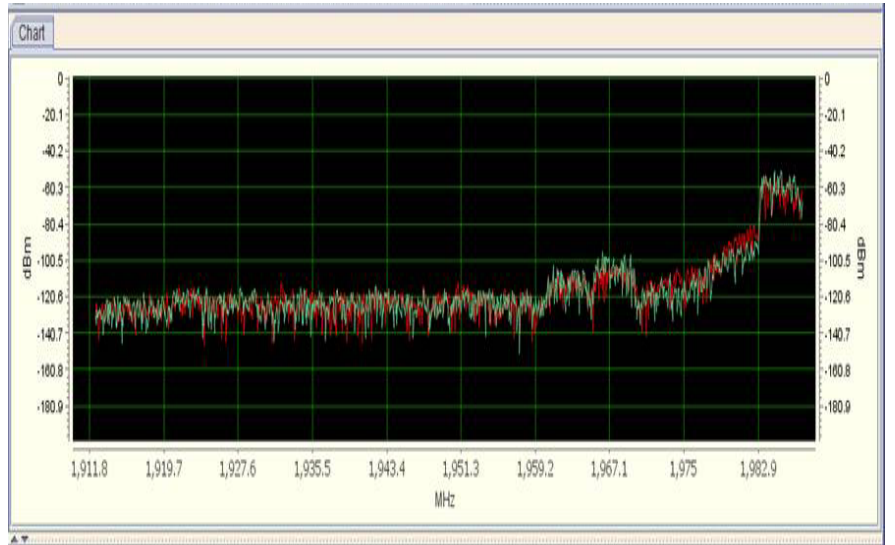

Gambar 12. Spektrum analyzer node 3614387G_Patimura barat.

$C_{p}=1.273239544735163 \mathrm{e}-10 \mathrm{~F}=0,1273 \mathrm{nF}$

$C_{s}=2.055787324548494 \mathrm{e}-14 \mathrm{~F}=0,0206 \mathrm{pF}$

$L_{p}=5.139468311371236 \mathrm{e}-11 \mathrm{H}=0,0514 \mathrm{nH}$

$L_{s}=3.183098861837907 \mathrm{e}-07 \mathrm{H}=318 \mathrm{nH}$

Setelah mendapatkan nilai elemen $L_{s}, C_{s}, L_{p}$, dan $C_{p}$. Langkah selanjutnya dengan memasukan nilai inputan seperti pada syntax matlab berikut sebagai fungsi dari circuit two half section. Kemudian diikuti berturut turut dengan syntax ekstrak 
$\mathrm{S}$ parameter dari 2 port network, pembuktian rational fit yang sudah sesuai.

Susunan elemen LC seri maupun pararel $L_{s}, C_{s}, L_{p}$, dan $C_{p}$ pada band pass filter circuit two half section dapat dilihat pada Gambar 13. Pada Gambar 13 terdapat tiga buah pole dengan susunan komponen dua LC seri dan susunan komponen satu LC pararel yang sudah didigabung (shunt tank), rangkaian seperti gambar berikut merupakan two half section yang sudah disederhanakan rangkaian pararelnya.

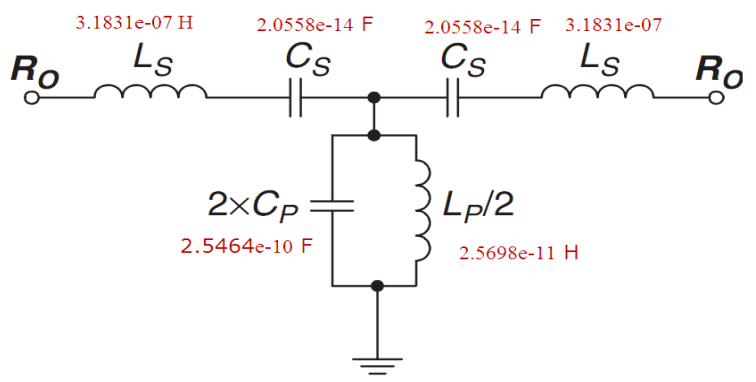

Gambar 13. Susunan nilai elemen LC pada band pass filter two half section

Hasil simulasi dengan Matlab2015a band pass filter circuit two half section untuk plot sinyal input, sinyal noise dan input (input yang sudah dipengaruhi oleh noise), serta output band pass filter dalam domain waktu dapat dilihat pada Gambar 14. Dari Gambar 14 didapatkan pemodelan sinyal input, noise dan input serta output filter. Terlihat bahwa amplitudo (volts) dari sinyal output filter lebih rendah dari signal input filter. Ini mengindikasikan bahwa sinyal input yang dipengaruhi noise yang sudah dilewatkan pada simulasi BPF mengalami proses filtering. Sinyal output filter yang dihasilkan dari proses filtering BPF dapat dilihat pada gambar sinyal output filter.

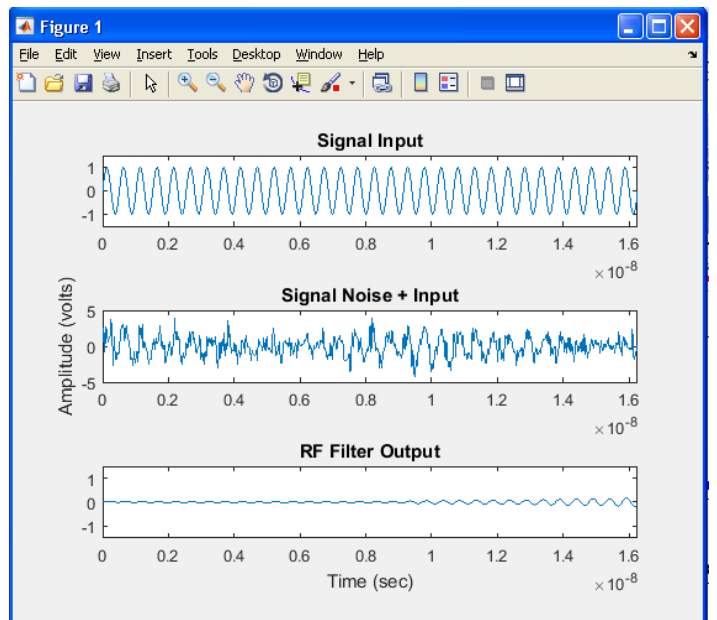

Gambar 14. Plot input signal, noisy input signal,dan band pass filter output dalam time domain circuit two half section

Plot filter respon, karakteristik filter, dan input spektrum noise dalam domain frekuensi circuit two half section dapat dilihat pada Gambar 15 berikut. Dari gambar 15 terlihat

M.Adi Surya Antara:Metode RF Filter untuk ... bahwa respon filter menunjukan cut off frekuensi $f_{1 c}$ pada $1955 \mathrm{MHz}$ dan $f_{2 c}$ pada $1980 \mathrm{MHz}, f_{\text {center }}$ pada point 1967,5 $\mathrm{MHz}$, slope atau kecuraman menunjukan dinding filter lebih curam dari circuit half section, dan tidak ada ripple amplitude pada signal yang di bandpasskan. Dapat diketahui juga bahwa besaran output setelah proses filter dilakukan menghasilkan magnitude output yang lebih rendah dari magnitude input dan noise. Pada circuit two half section kondisi penurunan magnitude output lebih rendah dari magnitude output pada circuit half section. Tampak pada Gambar 15 karakteristik filter dan input spektrum noise dalam domain frekuensi, inputan+noise yang ada dalam bandwidth $1.85 \mathrm{MHz}-1.9$ $\mathrm{MHz}$ tidak dilewatkan dalam output filter tetapi di reject atau stop band sehingga efek interferensi bisa dihilangkan dalam band frekuensi ini.

Dari simulasi band pass filter yang telah dilakukan peneliti dimulai dari circuit half section, two half section, dan third half section terlihat bahwa nilai slope (kecuraman dinding impulse respon) dan RF filter output yang paling baik dihasilkan dari circuit band pass filter two half section. Berdasarkan hasil simulasi tersebut maka model $R F$ filter yang diimplementasikan pada node yang terdapat nilai RTWP tinggi adalah tipe bandpass filter circuit two half section butterworth. Adapun speksifikasi $R F$ filter yang diimplementasikan pada Tabel 1:

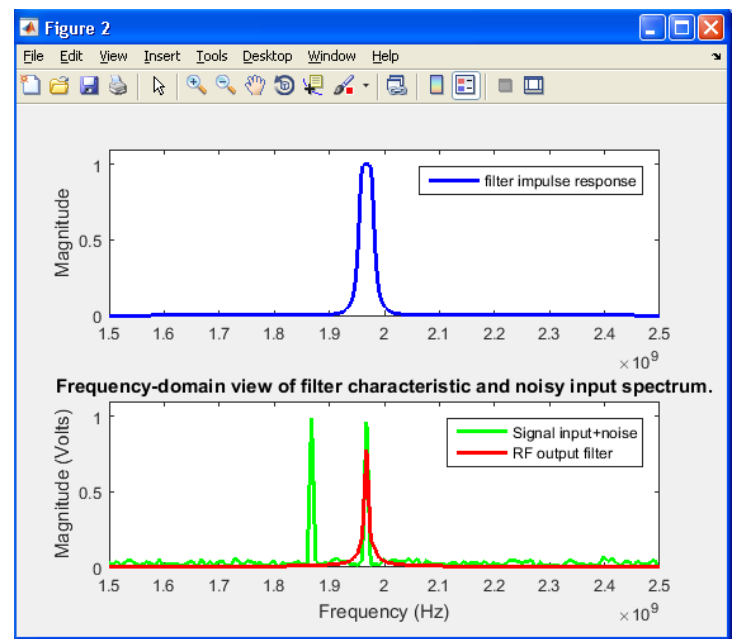

Gambar 15. Input signal dan filter response dalam frekuensi domain circuit two half section

Tabel 1. Spesifikasi band pass filter two half section.

\begin{tabular}{|c|c|c|c|c|}
\hline ITEM & \multicolumn{2}{|c|}{ Specifications } & \multicolumn{2}{|c|}{ Test Data } \\
\hline \multirow{2}{*}{$\begin{array}{c}\text { Frequency } \\
\text { Range }\end{array}$} & \multirow{2}{*}{\multicolumn{2}{|c|}{$\begin{array}{l}\text { UMTS UL(Rx) 1955MHz- } \\
\text { 1980MHz } \\
\text { UMTS DL(Tx) } 2145 \mathrm{MHz}- \\
2170 \mathrm{MHz}\end{array}$}} & \multirow{2}{*}{ Up } & \multirow{2}{*}{ Down } \\
\hline & & & & \\
\hline \multicolumn{5}{|l|}{ UMTS UL (Rx) } \\
\hline \multirow{2}{*}{ Insertion Loss } & Typical & $\begin{array}{c}0.7 \mathrm{~dB} \\
\max \end{array}$ & 0.21 & 0.18 \\
\hline & Egde & $\begin{array}{c}1.0 \mathrm{~dB} \\
\max \end{array}$ & 0.89 & 0.88 \\
\hline Return Loss & \multicolumn{2}{|c|}{$18 \mathrm{~dB}$ min } & 20.08 & 21.28 \\
\hline
\end{tabular}

p-ISSN:1693 - 2951; e-ISSN: 2503-2372 


\begin{tabular}{|c|c|c|c|c|}
\hline Rejection & $\begin{array}{c}@ 1983 \mathrm{MHz}- \\
1990 \mathrm{MHz}\end{array}$ & $\begin{array}{c}65 \mathrm{~dB} \\
\mathrm{Min}\end{array}$ & 66.26 & 66.31 \\
\hline UMTS DL (Tx) & Typical & $\begin{array}{c}0.5 \mathrm{~dB} \\
\mathrm{Max}\end{array}$ & 0.18 & 0.15 \\
\hline Insertion Loss & $18 \mathrm{~dB}$ min & 20.75 & 23.60 \\
\hline Return Loss & $\begin{array}{c}\text { @ } 1983 \mathrm{MHz}- \\
1990 \mathrm{MHz}\end{array}$ & $\begin{array}{c}65 \mathrm{~dB} \\
\mathrm{Min}\end{array}$ & 66.14 & 66.25 \\
\hline Rejection & $1.0 \mathrm{~dB}$ Max & 0.21 & 0.22 \\
\hline DC/AISG (DC-3.0MHz) & 25.54 & 25.61 \\
\hline Insertion Loss & $12 \mathrm{~dB}$ Min \\
\hline Return Loss
\end{tabular}

\section{$B$. Implementasi $R F$ band pass filter}

Menyesuaikan dengan hasil simulasi yang paling optimal dari $R F$ band pass filter yang telah dilakukan pada Sub Bab sebelumnya, maka dilanjutkan dengan skenario II yaitu proses implementasi $R F$ band pass filter pada node $3614387 \mathrm{G}$ Pattimura Barat. Adapun nilai RTWP untuk node 3614387G Pattimura Barat setelah implementasi $R F$ filter dapat dilihat pada Gambar 16:

Dari Gambar 16 dapat dilihat hasil scanning RTWP dengan LMT bahwa nilai RTWP pada node 3614387G_Patimura barat nilai berada pada range $-105 \mathrm{dBm}$ sampai $-103 \mathrm{dBm}$. Hasil ini menunjukan bahwa nilai RTWP pada node mengalami perbaikan, dimana sebelum implementasi RF filter nilai berada pada range $-89,6 \mathrm{dBm}$ sampai -86,4 dBm. Hal ini menjelaskan bahwa setelah pemasangan $R F$ filter circuit two half section nilai RTWP mengalami perbaikan dan efek interferensi bisa dihilangkan pada node UMTS.

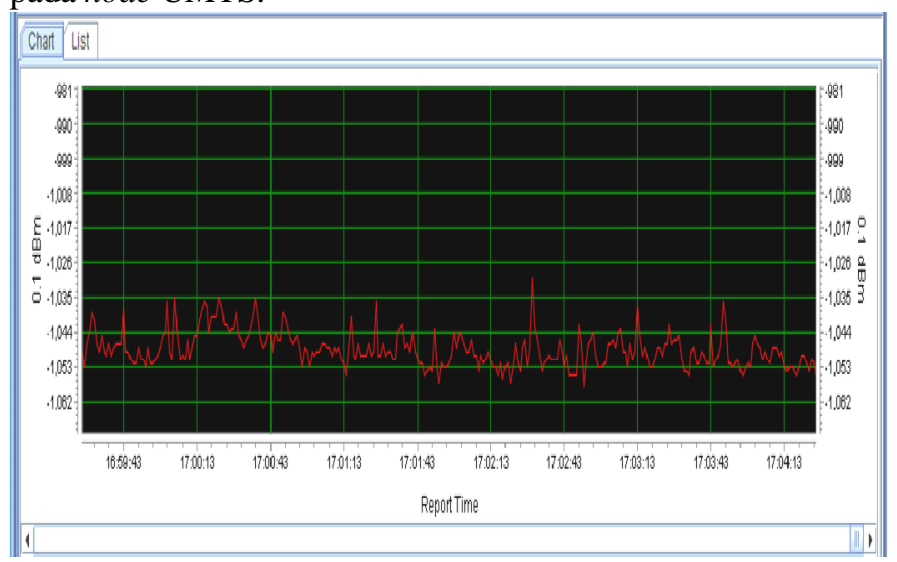

Gambar 16. Scanning RTWP node $3614387 \mathrm{G} \_$Patimura barat setelah implementasi $R F$ Filter.

\section{Kesimpulan}

Dari hasil analisis yang telah dilakukan pada penerapan metode $R F$ filter, maka dapat ditarik beberapa kesimpulan sebagai berikut :

1. Output dari $R F$ filter yang terbaik didapatkan dari tipe circuit two half section dengan nilai impedansi $\frac{Z_{\text {in }}}{Z_{\text {out }}}=$ $50 \Omega$, dimana dengan banyaknya jumlah pole rf circuit memberikan filter impulse respon yang lebih baik dilihat dari slope RF filter serta nilai magnitude output filter yang lebih rendah, namun memberikan $R F$ filter output yang kurang baik dilihat dari besaran amplitudo yang dihasilkan.

2. Hasil scanning RTWP pada jaringan UMTS operator menunjukan hasil perbaikan setelah proses implementasi $R F$ filter. Seperti ditunjukan pada node 3614387G_Patimura barat. Sebelum implementasi nilai RTWP berfluktuasi diantara $-89,6 \mathrm{dBm}$ sampai $-86,4$ $\mathrm{dBm}$ dan setelah implementasi $R F$ filter node mengalami perbaikan nilai RTWP $-105 \mathrm{dBm}$ sampai $-103 \mathrm{dBm}$

\section{REFERENSI}

[1] Wahyu P, Endroyono, Suwadi. "Solusi Menekan Interferensi Co-Channel dan Adjacent Channel pada Sistem Seluler WCDMA Multi Operator". JURNAL TEKNIK POMITS Vol. 1, No. 1, 2014. 1-6

[2] Gustavo Nader, Ultra Wideband Interference on ThirdGeneration Wireless Networks. Dissertation submitted to the Faculty of the Virginia Polytechnic Institute and State University. 2006

[3] O.C Nosiri, G.N. Onoh, V.E. Idigo, and C.O. Ohaneme. "Mechanisms and Industry Solutions for RF Interference in a Co-located Network", Journal of Communications Engineering and Networks, July. 2014, Vol. 2 Iss. 3, PP. $92-$ 102.

[4] E.T.Tchao, W.K.Ofosu, K.Diawuo, E.Affum dan Kwame Agyekum. "Interference Simulation and Measurements for aDeployed 4G-WiMAX Network In an Urban Sub-Saharan African Environment, International Journal of Computer Applications (0975-8887) Volume 71-No.14, june 2013.

[5] O. C. Nosiri, V. E. Idigo, C. O. Ohaneme, K. A. Akpado. "Coverage and Capacity Performance Degradation on a CoLocated Network Involving CDMA2000 and WCDMA @ 1.9GH , World Academy of Science, Engineering and Technology International Journal of Computer, Information, Systems and Control Engineering Vol:8 No:3, 2014

[6] Cotter W. Sayre, Complete Wireless Design, by The McGraw-Hill Companies, Inc 2008

[7] Buletin info SDPPI, Menkominfo. Media Informasi dan Komunikasi Ditjen Sumber Daya dan Perangkat Pos dan Informatika Kementerian Komunikasi dan Informatika. Edisi kelima 2013

[8] Ralf Kreher 2006, UMTS performance measurement, A Practical guide to KPIs for the UTRAN environment. John wiley\&Son, Ltd

[9] Lingga Wardhana. 2011 2G/3G RF Planning and Optimization for Consultant

[10] NodeB V200R013 Technical description, Huawei technologies co Ltd. 2011

[11] Kerry Lacanette. 1991 A Basic Introduction to Filters Active, Passive, and Switched-Capacitor NationalSemiconductor. Application Note 779 